\title{
Sterilization practices and hospital infections: Is there a relationship?
}

\author{
Duygu PERÇiN \\ Erciyes University Faculty of Medicine, Department of Clinical Microbiology, Kayseri, Turkey
}

\begin{abstract}
SUMMARY
Reprocessing of medical instruments is a series of steps involving transfer, pre-cleaning and decontamination, preparation and maintenance, packaging, sterilization, and storage until the moment of use. Good sterilization practices in hospitals require written standard operational procedures (SOP), compliance with national and international guidelines and norms, employing trained staff and continuing their education, validating and monitoring the process, recording all steps taken during the process, and maintaining successful quality management. All of the literature reporting a relationship between hospital infections and sterilization are, in fact, cases or epidemics originating from poor or bad sterilization practices.
\end{abstract}

Keywords: Hospital infection; reprocessing of medical instruments; sterilization.

E very day numerous surgical procedures are performed at hospitals all around the world; infection is a major risk for patients if medical instruments are not reprocessed the way they should be ${ }^{[1-4]}$ Failure to properly reprocess medical instruments risks cross infection from other patients or the environment, ${ }^{[5-9]}$ as has been reported in the literature following instances of infection that occurred due to poor sterilization practices.

Reprocessing medical instruments is a series of steps involving transfer, pre-cleaning and decontamination, preparation and maintenance, packaging, sterilization, and storage until the moment of use. In each of these steps, it is essential to adhere to defined rules of national and/or international guidelines. ${ }^{[1-4]}$ The best way to ensure that rules are followed by all mem- bers of staff is to have written standard operating procedures (SOP) and to define the required workflow of the Central Sterile Supply Department (CSSD). SOP give more structure to activities. Well-written SOP explained visually through a flowchart or annotated illustrations, if needed, help staff members to do their jobs well. ${ }^{[1]}$

Medical devices used in hospitals are guaranteed by the Medical Device Directive (MDD) in European Union (EU) member countries. According to this directive, member countries must take all necessary steps to ensure that devices are only placed on the market and put into service if they do not compromise the safety and health of patients, users and, where applicable, other persons, when properly installed, maintained and used in accordance with their intended purpose. ${ }^{[10]}$

How to cite: Perçin D. Sterilization practices and hospital infections: Is there a relationship? Int J Antisep Disinfect Steril 2016;1(1):19-22.

Correspondence: Duygu Perçin, MD. Prof. Erciyes University Faculty of Medicine,

Department of Microbiology, Kayseri, Turkey.

Tel: +90352 - 2076666 / 23383 e-mail: duygu.percin@hotmail.com

Submittedः March 25, 2016 Acceptedः April 08, 2016 Available online dateः May 05, 2016 
The elimination of microorganisms from a device during the sterilization process is time-dependent, influenced by the intensity of the process and level of initial microbial contamination. After every operation, surgical instruments are contaminated with blood and microorganisms to varying degrees, depending on the type of operation. There are few studies of accurate estimates of number of microorganisms on used medical surgical instruments. Lumened instruments are more challenging for the CSSD staff. Controversy exists concerning degree of microbial contamination associated with use of rigid lumened medical devices, efficacy of standard cleaning techniques used to remove pathogenic microorganisms from lumen channels, and risk of cross infection because of microbial contamination. Chan-Myers et $\mathrm{al}^{\left[{ }^{[11]}\right.}$ conducted research on the level and types of microorganisms found on rigid lumened medical devices pre and post cleaning. The bioburden level after clinical use was found to be relatively low, ranging from 10 to $10^{4}$ colony-forming units (CFU) per device. The bioburden level was also related to the anatomical site where the device was used, with fewer organisms found on devices exposed to sterile body sites and the respiratory tract.

In addition to initial number of microorganisms, time before reprocessing is also critical for effective cleaning and to achieve sterility assurance level. Perçin et $\mathrm{al}^{\left[{ }^{[12]}\right.}$ reported that cleaning surgical instruments in first 6 hours after use is essential in order to ensure effective disinfection and sterilization. They proved that bacterial count on a used instrument starts to increase logarithmically after 6 hours at room temperature and reaches up to $3 \log 10 \mathrm{CFU} / \mathrm{cm}^{2}$ after 12 hours.

Inadequate cleaning of reusable surgical instruments is a common error. One of the most important reasons for inadequate cleaning is lack of sufficient number of instruments at the hospital. Staff is forced to shorten reprocessing time because of the large number of patients. In particular, special attention is required to clean lumened and complex instruments, such as those used for arthroscopy. In a case-control study following a surgical site infection due to Pseudomonas aeruginosa in a patient who underwent arthroscopic surgery in 2009 in Texas, it was proven that the lumens of the complex, structured instruments used during arthroscopy had not been cleaned well. ${ }^{[8]}$

Routine sterilization in CSSDs always includes a number of uncertainties linked to noncondensable gases, insufficient cleaning and excessive condensate. These risks may lower sterilization efficacy, consequently endangering the patient's life and can lead to outbreaks of infection in surgical departments. Perçin et al. ${ }^{[13]}$ con- firmed with an experimental study using large numbers of spores that excessive condensate has a high impact on sterilization efficacy. This impact could only be seen with spore inoculum of more than 108.

While the appropriate size and weight of sterilization packs to be used are clearly defined in all sterilization guidelines and norms, sometimes these guidelines are not consistently followed. Microbiological results of an epidemiological survey focused on central sterilization unit proved that the cause of an outbreak of Serratia marcescens mediastinitis in a cardiac surgery intensive care unit (ICU) was the use of inadequately decontaminated theatre linen. Aside from lack of control and monitoring of sterilization processes, the most important problem reported was excessive weight of theatre linen packs. ${ }^{[7]}$ It should also be noted that classic cotton textile drapes have no efficient microbial barrier according to International Organization for Standardization (ISO) standard $13795 .^{[14]}$ In addition to its inefficient bacterial barrier, folding and packaging textile drapes increases the number of particles in clean area of CSSD, which must comply with ISO 8 cleanroom standards. ${ }^{[1,15]}$

A scandal occurred in Oklahoma in March 2013 because dental instruments were used without being sterilized. Some 7000 patients were screened for Hepatitis B virus (HBV), Hepatitis $\mathrm{C}$ virus (HCV), and human immunodeficiency virus (HIV) as a result of this scandal. ${ }^{[6]}$ Deviating from best practices in sterilization process or failing to comply with basic rules can lead to infection. Moreover, bad sterilization practices that are not compatible with national or international guidelines increase the risk.

Brophy et al. ${ }^{[16]}$ reported another problem that may affect decontamination procedures. They examined 4800 new surgical instruments ordered by several hospitals in United Kingdom (UK). They reported that $15 \%$ of the instruments had potential problems, including machining burrs and debris in the teeth of tissue-holding areas, ratcheting, deficient cutting action, protruding guide pins, and corrosion. This study demonstrates the value of quality control for new surgical instruments. Blood and tissue debris may collect in an imperfect surface and be impossible to clean adequately. There is added concern because prion diseases may survive routine sterilization processes. ${ }^{[17]}$

Misuse of immediate-use sterilization (flash sterilization) is another example of bad practice. This process is complex and requires a facility to consistently follow the necessary steps to ensure sterility of instruments to the point of use. Improper technique can result in use of contaminated instruments in surgery, which could have 
serious consequences, including surgical site infections. ${ }^{[4]}$ Hutzler et al. ${ }^{[18]}$ designed a system to reduce immediateuse sterilization at their hospital by instituting a policy requiring nursing leaders to approve use of immediateuse sterilization, developing guidelines, and monitoring compliance daily. The use of immediate-use sterilization decreased from $79 \%$ in 2010 to $7.5 \%$ in 2012 . There was also improvement in incidence of surgical site infection, decreasing from $5.4 \%$ in 2010 to $1.4 \%$ in 2012. Facilities should increase their surgical instrument inventory, employ a scheduling conflict mechanism, improve communication between operating room and sterile processing personnel, and educate all those employing immediateuse steam sterilization. ${ }^{[1,4]}$

A final, but no less important, problem regarding poor sterilization practices is reuse of single-use devices. Medical devices may only be reused if the manufacturer provides information about the appropriate process, including cleaning, disinfection, packaging, and sterilization. $\mathrm{MDD}^{[10]}$ therefore prohibits reuse of medical devices labeled "single-use" and therefore have no instructions for reuse. Scientific Committee on Emerging and Newly Identified Health Risks (SCENIHR) ${ }^{[19]}$ provided a report to European Commission in 2010 concluding that reusing single-use devices presents risk of infection, toxic reaction due to disinfectant residue, and changes to physical and chemical characteristics of the devices that may eventually impact their performance.

In conclusion, for good sterilization practices, it is necessary to have written SOP, to comply with national and international guidelines and norms, to employ trained staff and to continue their education, to not reprocess single-use devices, to monitor and validate reprocessing cycles, to record all steps performed during the process and to sustain successful quality management. There is no relationship between sterilization and hospital infections when good sterilization practices are followed.

\section{Conflict of interest: None declared.}

Peer-review: Externally peer-reviewed.

Authorship contributions: Concept - Design - Supervision - Resource - Materials - Data collection - Literature search - Writing: D.P.

\section{References}

1. McDonnell GE. Antisepsis, Disinfection and Sterilization. Washington DC, USA: ASM Press, American Society for Microbiology, 2007. Crossref

2. Günaydın M, Perçin D, Esen Ş, Zenciroğlu D. Dezenfeksiyon ve Sterilizasyon Rehberi. İstanbul: Gülmat Matbaacılık;
2015.

3. Robert Koch Institute. Recommendations by the Commission for Hospital Hygiene and Infection Prevention at the Robert Koch Institute and the Federal German Institute for medical drugs and medical products concerning the "Hygienic requirements for processing of medical devices." Bundesgesundheitsbl. Gesundheitsforsch. Gesundheitsschutz 2001, 44: 1115-1126, Springer Verlag. (www.rki.de).

4. Rutala WA, Weber DJ, and the Healthcare Infection Control Practices Advisory Committee (HICPAC). Guideline for Disinfection and Sterilization in Healthcare Facilities, 2008.

5. Schmidt PT. Hygiene-Skandal im Klinikum Bogenhausen. Available at: http://www.merkur.de/lokales/muenchen/ stadt-muenchen/hygiene-skandal-klinikum-bogenhausen-833838.html (Accession date: 09/07/2016).

6. LeBlonde L. Oklahoma dental clinic may have infected thousands with HIV and Hepatitis. Available at: http://www.redorbit.com/news/health/1112812993/hiv-hepatitis-instruments-oklahoma-dental-clinic (Accession date: 29/03/2013).

7. Esel D, Doganay M, Bozdemir N, Yildiz O, Tezcaner T, Sumerkan B, et al. Polymicrobial ventriculitis and evaluation of an outbreak in a surgical intensive care unit due to inadequate sterilization. J Hosp Infect 2002;50:170-4. Crossref

8. Tosh PK, Disbot M, Duffy JM, Boom ML, Heseltine G, Srinivasan $\mathrm{A}$, et al. Outbreak of Pseudomonas aeruginosa surgical site infections after arthroscopic procedures: Texas, 2009. Infect Control Hosp Epidemiol 2011;32:1179-86. Crossref

9. Dancer SJ, Stewart M, Coulombe C, Gregori A, Virdi M. Surgical site infections linked to contaminated surgical instruments. J Hosp Infect 2012;81:231-8.

10. Council Directive 93/42/EEC of 14 June 1993 concerning medical devices. Official Journal L 1993;169:1-43. Available at: http://eur-lex.europa.eu/legal-content/EN/ TXT/?uri=OJ:L:1993:169:TOC.

11. Chan-Myers H, McAlister D, Antonoplos P. Natural bioburden levels detected on rigid lumened medical devices before and after cleaning. Am J Infect Control 1997;25:471-6. Crossref

12. Percin D, Sav H, Hormet-Oz HT, Karauz M. The relationship between holding time and the bacterial load on surgical instruments. Indian J Surg 2015;77:16-8. Crossref

13. Percin D, Kozin P, Renders W. The impact of excessive condensate on the sterility assurance level. Central Service 2015;1:40-3.

14. EN 13795:2011. Surgical drapes, gowns and clean air suits, used as medical devices for patients, clinical staff and equipment - General requirements for manufacturers, processors and products, test methods, performance requirements and performance levels, 2011.

15. ISO 14644-1:2015. Cleanrooms and associated controlled environments - Part 1: Classification of air cleanliness by particle concentration, 2015.

16. Brophy T, Srodon PD, Briggs C, Barry P, Steatham J, Birch MJ. Quality of surgical instruments. Ann R Coll Surg Engl 


\section{6;88:390-3. Crossref}

17. Lemmer K, Mielke M, Pauli G, Beekes M. Decontamination of surgical instruments from prion proteins: in vitro studies on the detachment, destabilization and degradation of PrPSc bound to steel surfaces. J Gen Virol 2004;85(Pt 12):380516. Crossref

18. Hutzler L, Kraemer K, Iaboni L, Berger N, Bosco JA 3rd. A hospital-wide initiative to eliminate preventable causes of immediate use steam sterilization. AORN J 2013;98:597-607. Crossref

19. Scientific Committee on Emerging and Newly Identified Health Risks. The Safety of Reprocessed Medical Devices Marketed for Single-Use. European Commission 2010 ISSN 1831-4783 ISBN 978-92-79-12729-8.

\section{Sterilizasyon uygulamaları ve hastane enfeksiyonları: Bir ilișki var mı?}

\section{Duygu PERÇiN}

Tıbbi aletlerin yeniden kullanıma hazırlanması işlemi, transfer, ön-temizlik ve dekontaminasyon, hazırlık ve bakım, paketleme, sterilizasyon, depolama, kullanım anına kadar sterilliği korunarak saklama basamaklarının tümünü içeren bir işlemler dizisidir. Hastanelerde iyi sterilizasyon uygulamaları için yazılı protokollerin oluşturulması, ulusal ve uluslararası kılavuzlara uyulması, eğitimli personel istihdamı ve eğitimin devamlılığı, tüm sürecin kontrolü ve validasyonu, tüm işlemlerin kayıt altına alınması ve başarılı bir kalite yönetimi zorunludur. Literatürde hastane enfeksiyonları ile sterilizasyon uygulamaları arasında bağ olduğunu gösteren tüm vakalar aslında kötü veya yanlış uygulamalardan kaynaklanan olgular ve salgınlardır.

Anahtar sözcükler: Hastane enfeksiyonları; sterilizasyon; tıbbi aletlerin yeniden kullanıma hazırlanması.

Int J Antisep Disinfect Steril 2016;1(1):19-22 doi: 10.14744/ijads.2016.76476 